\title{
Pelindian Natrium Zirkonat Menggunakan Asam Klorida Secara Catu
}

\author{
Sodium Zirconate Leaching Using Hydrochloric Acid on \\ Batch Process
}

\author{
Sajima* \\ Pusat Sains dan Teknologi Akselerator-BATAN \\ Jln. Babarsari, Kotak Pos 6101 ykbb, Yogyakarta 55281 \\ Telp (0274) 488435, Fax (0274)489762 \\ *E-mail: sajima@batan.go.id
}

Naskah diterima: 19 April 2018, direvisi: 25 Mei 2018, disetujui: 31 Mei 2018

DOI: $\underline{10.17146 / \text { eksplorium.2018.39.1.4369 }}$

\begin{abstract}
ABSTRAK
Penelitian tentang teknologi pengolahan zirkon terus dilakukan untuk mengikuti kebutuhan industri pasar. Pengolahan natrium zirkonat dengan pelindian menggunakan asam klorida sebagai pelarut telah dilakukan. Penelitian ini bertujuan mempelajari pengaruh ukuran butir, temperatur, dan kecepatan pengadukan terhadap zirkon terambil. Penelitian dilakukan dengan memasukkan pelarut (asam klorida $4 \mathrm{~N}$ ) ke dalam reaktor, kemudian pelarut tersebut dipanaskan sambil diaduk. Umpan dengan ukuran butir tertentu dimasukkan ke dalam reaktor. Kondisi temperatur dan kecepatan pengadukan dijaga tetap. Setelah kondisi operasi tercapai, proses dihentikan kemudian disaring. Hasil penelitian dengan analisis XRF menunjukkan bahwa kondisi proses optimum dicapai pada ukuran butir $90 \mu \mathrm{m}$, temperatur $80{ }^{\circ} \mathrm{C}$ dan kecepatan pengadukan $200 \mathrm{rpm}$. Pada kondisi tersebut zirkon terambil sebesar $84,50 \%$.
\end{abstract}

Kata kunci: pelindian, zirkon, temperatur, pengadukan, butiran

\begin{abstract}
Research on zircon processing technology has been continued to follow industrial market needed. Treatment of sodium zirconate with leaching process using hydrochloric acid as solvent has been conducted. The aim of the study is to evaluate the effect of grain size, temperature, and speed of stirring on the extracted zircon. The research starting with introduced the solvent (chloride acid $4 \mathrm{~N}$ ) into the reactor, then heated while stirring. The feed with a certain grain size was introduced into the reactor. The temperature and stirring conditions were kept steady. Once the operating conditions are reached, the process is stopped and then filtered. The results with XRF analysis showed that the optimum process conditions were achieved on $90 \mu \mathrm{m}$ grain size, the temperature of 80 ${ }^{\circ} \mathrm{C}$, and stirring speed of $200 \mathrm{rpm}$. The amount of zircon that taken out were $84.50 \%$ on this conditions.
\end{abstract}

Keywords: leaching, zirconate, temperature, stirring, grain

\section{PENDAHULUAN}

Undang-Undang Minerba Nomor 9 Tahun 2009 tentang Pertambangan Mineral dan Batubara melalui Peraturan Menteri ESDM Nomor 5 Tahun 2017 menjelaskan adanya larangan penjualan bijih (raw material atau ore) mineral ke luar negeri, termasuk di dalamnya mineral zirkon $\left(\mathrm{ZrSiO}_{4}\right)$ [1]. Mineral zirkon secara alamiah termasuk bijih kadar rendah (low grade/lateric ores) dan merupakan mineral ikutan penambangan emas [2]. 
Mineral zirkon apabila diolah lebih lanjut akan memiliki peran yang sangat strategis terkait dengan industri nuklir maupun industri aplikatif lainnya [3,4]. Pada industri nuklir, bahan ini dapat diolah menjadi zirkonia atau sebagai bahan keramik maju karena memiliki kekuatan yang tinggi dan titik lebur sangat tinggi $\left(2700{ }^{\circ} \mathrm{C}\right)$ [5]. Selain itu, bahan ini juga memiliki konduktivitas termal yang rendah, fleksibilitas yang tinggi, dan ketahanan terhadap korosi yang sangat baik sehingga dapat diaplikasikan sebagai bahan pembuatan sensor oksigen. Sensor oksigen digunakan untuk memantau konsentrasi oksigen pada sistem nuklir berpendingin lead alloy seperti pada LFR (Lead alloy-cooled Fast Reactor) maupun target spalasi pada ADS (Accelerator Driven System) [7].

Pengolahan mineral zirkon diawali dengan proses fisis dilanjutkan pemurnian secara kimiawi. Perangkat pengolahan secara fisis antara lain meja goyang, magnetik separator, dan high tension separator. Pemisahan menggunakan meja goyang merupakan proses pemisahan berdasarkan perbedaan massa jenis antarmineral sedangkan proses pemisahan menggunakan magnetik separator adalah proses pemisahan mineral berdasarkan perbedaan sifat kemagnetan mineral [6]. High tension separator merupakan perangkat pemisahan mineral berdasarkan perbedaan sifat kelistrikan mineral [8,9]. Hasil pemisahan mineral zirkon berupa konsentrat zirkon yang memiliki karakteristik diffraktogram seperti Gambar 1 [10].

Penelitian tentang pelarutan zirkon di dalam asam klorida yang pernah dilakukan antara lain pelarutan natrium zirkonat secara kontinu [8], pelindian secara bertingkat leburan konsentrat zirkon Brasil [11], dan konfirmasi bentuk $\mathrm{Na}_{2} \mathrm{ZrSiO}_{5}$ dalam proses peleburan pada pembuatan zirkon oksi khlorid [4]. Penelitian tersebut umumnya menggunakan $\mathrm{NaOH}$ sebagai reaktan pada saat proses peleburan. Pada penelitian ini umpan yang digunakan merupakan hasil peleburan dengan reaktan campuran $\mathrm{NaOH}$ dengan $\mathrm{CaO}$ karena menghasilkan leburan yang ramah lingkungan [12]. Skema pengolahan dari pasir zirkon menjadi Zirconium Oxychloride (ZOC) ditunjukkan oleh Gambar 2.

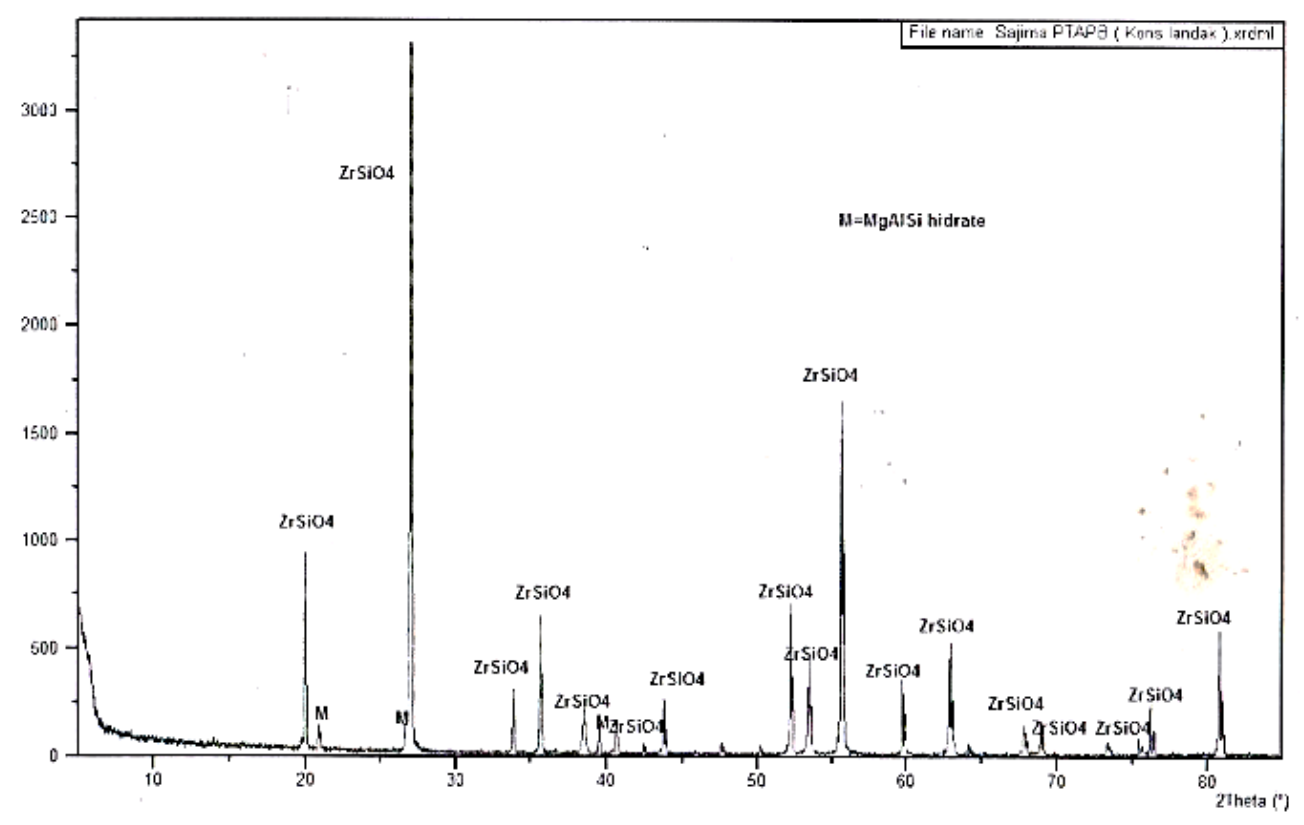

Gambar 1. Diffraktogram konsentrat zircon. 
Penelitian tentang pelarutan zirkon di dalam asam klorida yang pernah dilakukan antara lain pelarutan natrium zirkonat secara kontinu [8], pelindian secara bertingkat leburan konsentrat zirkon Brasil [11], dan konfirmasi bentuk $\mathrm{Na}_{2} \mathrm{ZrSiO}_{5}$ dalam proses peleburan pada pembuatan zirkon oksi khlorid [4]. Penelitian tersebut umumnya menggunakan $\mathrm{NaOH}$ sebagai reaktan pada saat proses peleburan. Pada penelitian ini umpan yang digunakan merupakan hasil peleburan dengan reaktan campuran $\mathrm{NaOH}$ dengan $\mathrm{CaO}$ karena menghasilkan leburan yang ramah lingkungan [12]. Skema pengolahan dari pasir zirkon menjadi Zirconium Oxychloride (ZOC) ditunjukkan oleh Gambar 2.

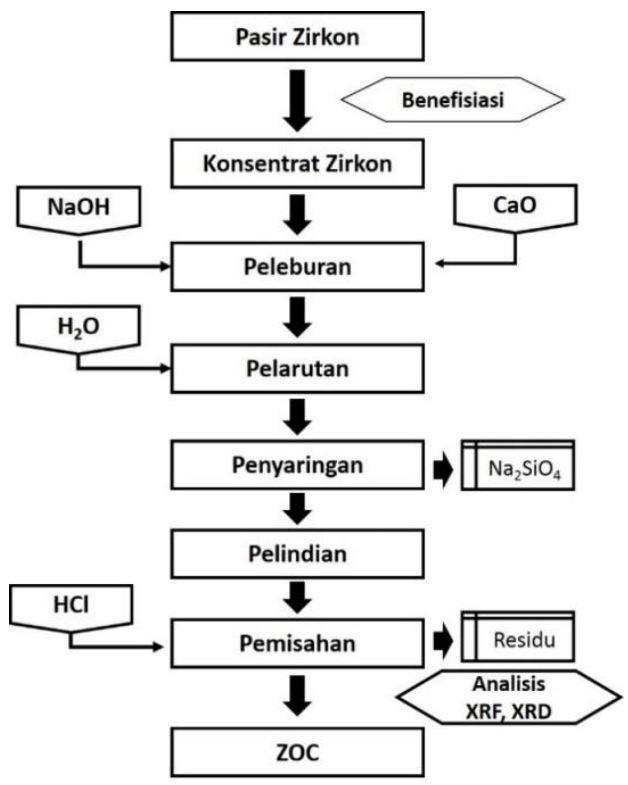

Gambar 2. Skema pengolahan mineral zirkon menjadi ZOC.

Mekanisme reaksi yang terjadi pada proses peleburan diharapkan sebagai berikut [12]:

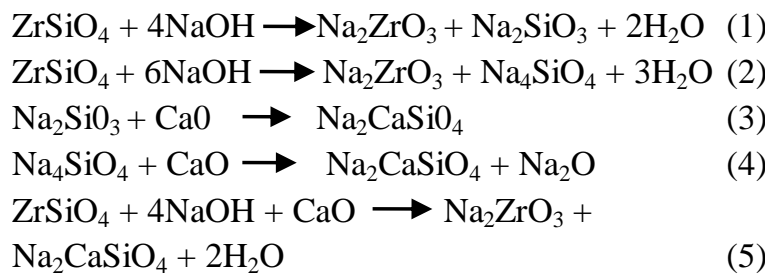

$\mathrm{Na}_{2} \mathrm{CaSiO}_{4}$ bersifat larut dalam air sedangkan $\mathrm{Na}_{2} \mathrm{ZrO}_{3}$ tidak larut dalam air. Perbedaan kedua sifat di atas digunakan sebagai dasar pemisahan bahan tersebut.

Mekanisme reaksi pelindian natrium zirkonat dengan asam klorida sebagai berikut:

$\mathrm{Na}_{2} \mathrm{ZrO}_{3}+4 \mathrm{HCl} \longrightarrow \mathrm{ZrOCl}_{2}+2 \mathrm{NaCl}+2 \mathrm{H}_{2} \mathrm{O}$

Faktor-faktor yang harus diperhatikan dalam proses pelindian antara lain [11]:

a. Ukuran partikel

Semakin kecil ukuran partikel maka areal terbesar antara padatan terhadap cairan memungkinkan terjadi kontak secara tepat. Semakin besar partikel maka waktu yang diperlukan oleh cairan yang akan mendifusi relatif lebih lama.

b. Pengadukan

Pengadukan sangat erat hubungannya dengan sistem pendispersian butir padatan ke dalam cairan sehingga kontak molekul semakin luas dan memperbesar tumbukan antarmolekul dalam cairan. Kecepatan pengadukan merupakan parameter penting dalam pengadukan yang dinyatakan dengan gradien kecepatan [13]. Gradien kecepatan merupakan fungsi dari tenaga yang disuplai (P):

$$
G=\sqrt{\frac{P}{\mu V}}
$$

dimana $\mathrm{G}$ adalah gradien kecepatan, $\mathrm{P}$ adalah tenaga yang diberikan ke target (N.m/detik), $\mathrm{V}$ merupakan volume target yang diaduk $\left(\mathrm{m}^{3}\right)$, dan $\mu$ adalah viskositas absolut target $\left(\mathrm{N} . \operatorname{detik} / \mathrm{m}^{2}\right)$. Kenaikan kecepatan putaran pengadukan akan menaikkan power supply per satuan massa larutan yang akan mengakibatkan kecepatan pelarutan semakin meningkat. 


\section{c. Temperatur}

Pada umumnya jika temperatur dinaikkan, laju reaksi bertambah cepat. Hal ini dikarenakan semakin tinggi temperatur, gerak partikel-partikel pereaksi dan energi kinetik partikel akan ikut meningkat. Hubungan antara konstanta kecepatan reaksi (k) dengan temperatur mengikuti persamaan Arrhenius.

$$
k=A \cdot \operatorname{Exp} \cdot(-E / R T)
$$

dengan $\mathrm{k}$ adalah konstanta laju reaksi, A adalah konstanta integrasi/faktor frekuensi, E adalah energi aktivasi ( $\mathrm{kal} / \mathrm{mol}), \quad \mathrm{R}$ merupakan tetapan gas ideal yang bernilai 1,987 kal/mol.K, dan $\mathrm{T}$ adalah temperatur mutlak (K).

Cara untuk mengetahui keberhasilan atau efisiensi proses digunakan persamaan berikut [5]:

$$
\eta p=\left(\frac{\sum n-\sum p}{\sum n}\right) \times 100 \%
$$

dimana $\eta p$ adalah efisiensi proses, $\sum \mathrm{n}$ adalah jumlah total zirkon dalam umpan, dan $\sum \mathrm{p}$ adalah jumlah total zirkon dalam larutan (ZOC).

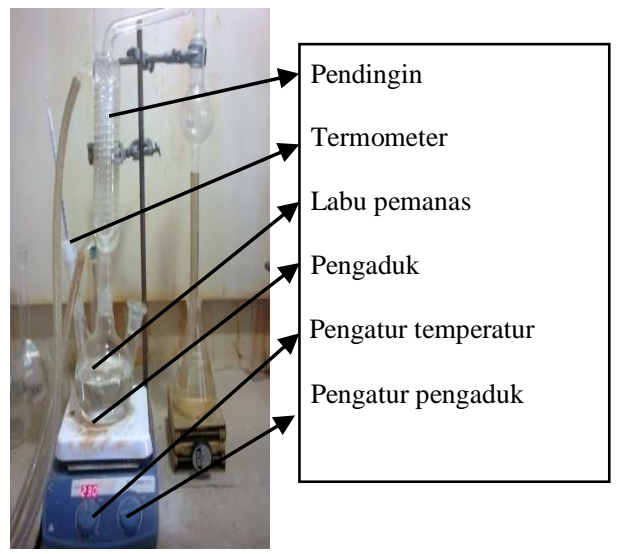

Gambar 3. Proses pelindian.

\section{TATA KERJA}

\section{Bahan Baku}

Bahan baku berupa konsentrat zirkon yang berasal dari Kalimantan dengan komposisi seperti yang ditunjukkan oleh Tabel 1.

Tabel. 1. Komposisi penyusun konsentrat zirkon

\begin{tabular}{ccc}
\hline No. & Nama oksida & Kadar (\%) \\
\hline 1 & $\mathrm{ZrO}_{2}$ & 22,03 \\
2 & $\mathrm{SiO}_{2}$ & 9,98 \\
3 & $\mathrm{TiO}_{2}$ & 38,58 \\
4 & $\mathrm{Fe}_{2} \mathrm{O}_{3}$ & 13,70 \\
5 & $\mathrm{HfO}_{2}$ & 0,287 \\
6 & $\mathrm{SnO}_{2}$ & 6,97 \\
7 & $\mathrm{Cr}_{2} \mathrm{O}_{3}$ & 1,56 \\
\hline
\end{tabular}

\section{Peralatan}

Peralatan yang digunakan terdiri dari timbangan, perangkat pelindian, penyaring vakum, dan satu unit Spektrofotometer pendar sinar X (XRF). Timbangan digunakan untuk menimbang bahan. Pelindian dilakukan dengan satu perangkat pelindian tegak yang dilengkapi dengan pemanas, pendingin, dan pengaduk. Penyaring vakum digunakan untuk memisahkan larutan dan padatan.

\section{Cara kerja}

Pembuatan umpan dilakukan dengan melakukan penimbangan yaitu $125 \mathrm{~g}$ konsentrat zirkon $137,5 \mathrm{~g} \mathrm{NaOH}$ teknis, kemudian dicampur hingga heterogen. Campuran yang diperoleh dimasukkan ke dalam tungku peleburan dan ditutup rapat. Tombol pengatur power pada tungku diposisikan on. Pengatur temperatur tungku diatur pada $800{ }^{\circ} \mathrm{C}$. Apabila temperatur tungku sudah tercapai maka proses dipertahankan selama 120 menit. Setelah waktu penahanan tercukupi, tombol pengatur power diposisikan pada off dan dibiarkan dingin.

Langkah selanjutnya berupa Percobaan Pelindian. Percobaan ini berlangsung dalam labu gelas pyrex dengan kapasitas $500 \mathrm{ml}$ yang dilengkapi dengan motor pengaduk, 
pemanas, dan pendingin. Mula-mula dimasukkan pelarut $(\mathrm{HCl} 4 \mathrm{~N})$ sebanyak 300 $\mathrm{ml}$ ke dalam bejana sambil diaduk pada kecepatan putar tertentu. Air pendingin dialirkan, kemudian pemanas dihidupkan hingga termometer menunjukkan angka tertentu. Setelah temperatur tercapai, umpan dengan ukuran tertentu sebanyak $10 \mathrm{~g}$ dimasukkan ke dalam bejana secara manual. Temperatur proses dan kecepatan pengadukan dipertahankan tetap selama 60 menit. Apabila waktu pelindian tercapai, perangkat proses dimatikan dan dibiarkan dingin. Hasil proses dipisahkan menggunakan penyaring vakum. Selanjutnya kandungan zirkon dalam umpan dan filtrat dianalisis menggunakan metode XRF. Penelitian dilakukan dengan memvariasi temperatur $(30,40,50,60,70$, 80 , 90, dan $100{ }^{\circ} \mathrm{C}$ ), kecepatan pengadukan $(25,50,75,100,125,150,175$, dan $200 \mathrm{rpm})$, serta ukuran butir $(240,200,160,90$, dan 40 $\mu \mathrm{m})$.

\section{HASIL DAN PEMBAHASAN}

Semakin besar ukuran butiran maka jumlah zirkon yang terambil semakin sedikit atau semakin kecil ukuran butiran umpan (90 $\mu \mathrm{m}$ menjadi $200 \mu \mathrm{m})$ mengakibatkan jumlah zirkon terambil semakin banyak. Hal ini membuktikan bahwa semakin kecil ukuran butiran, luas permukaan kontak antara padatan dengan pelarut semakin besar. Namun, ketika ukuran butiran diperhalus lagi (40 $\mu \mathrm{m}$ ), jumlah zirkon terambil tidak mengalami kenaikan yang berarti. Hal ini menunjukkan bahwa ukuran butir $90 \mu \mathrm{m}$ merupakan ukuran optimum untuk proses pelindian. Pengaruh ukuran butir pelindian terhadap zirkon terlarut disajikan pada Gambar 4.

Temperatur pelindian sangat mempengaruhi jumlah zirkon terikat dalam filtrat (larutan $\mathrm{HCl} \quad 4 \quad \mathrm{~N}$ ). Ketika proses pelindian dilakukan dengan menaikkan temperatur dari 30 hingga $80 \mathrm{oC}$, jumlah zirkon terambil mengalami kenaikkan secara signifikan $(63,50 \%$ menjadi 79,80\%) dengan grafik percobaan seperti pada Gambar 5.

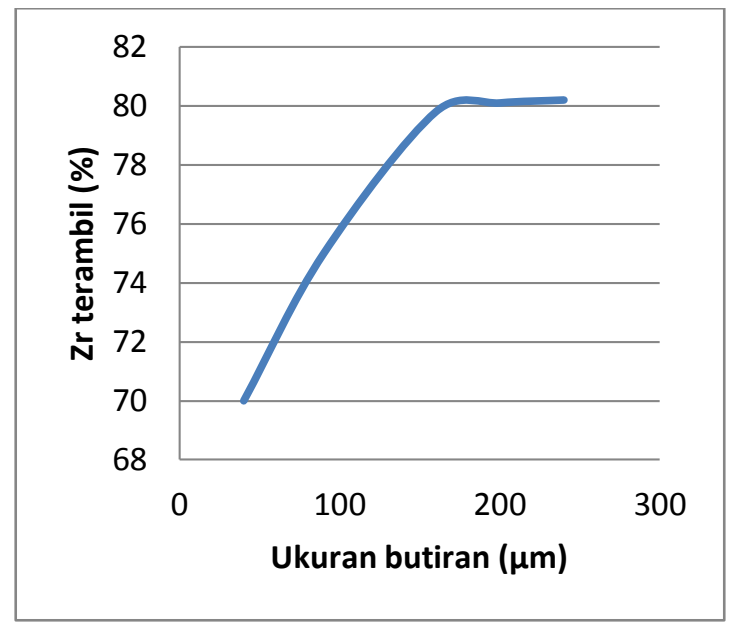

Gambar 4. Pengaruh ukuran butiran umpan pelindian selama 60 menit dengan kecepatan putar pengaduk 200 rpm terhadap zirkon terlarut dalam $\mathrm{HCl} .4 \mathrm{~N}$.

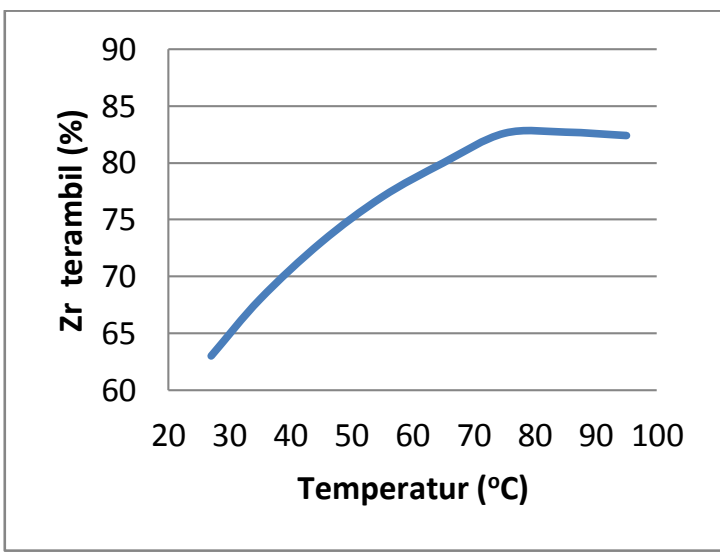

Gambar 5. Pengaruh temperatur pelindian selama 60 menit dengan kecepatan putar pengaduk $200 \mathrm{rpm}$ terhadap zirkon terlarut dalam $\mathrm{HCl} 4 \mathrm{~N}$.

Hal ini sesuai dengan persamaan (8) bahwa semakin tinggi temperatur menyebabkan tenaga kinetis yang dimiliki oleh molekul-molekul reaktan meningkat. Hal ini akan memacu gerakan zat lebih besar dan menimbulkan tumbukan antarmolekul semakin intens sehingga reaksi berjalan lebih sempurna. Namun, ketika temperatur proses 
dinaikkan lagi menjadi $90{ }^{\circ} \mathrm{C}$ diperoleh gambar grafik dengan garis mendatar. Kondisi ini menunjukkan bahwa proses pelindian terbaik terjadi pada temperatur $80 \mathrm{oC}$ dengan jumlah zirkon terambil sebanyak $82,90 \%$.

Persentase zirkon terambil dalam interval waktu yang sama mengalami kenaikan sangat signifikan (30,00\% menjadi 84,60\%) seiring dengan penambahan kecepatan pengadukan (40 rpm menjadi $200 \mathrm{rpm}$ ) seperti pada Gambar 6.

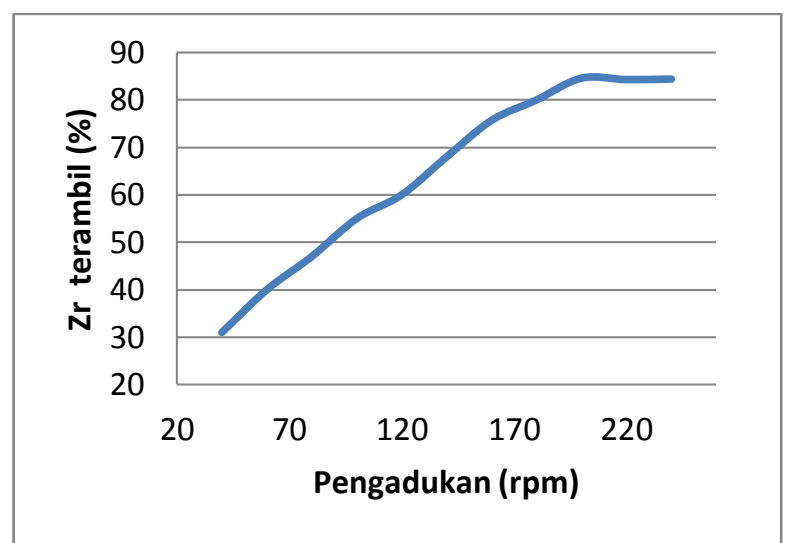

Gambar 6. Pengaruh kecepatan pengadukan pelindian selama 60 menit pada temperatur $80{ }^{\circ} \mathrm{C}$ terhadap zirkon terlarut dalam $\mathrm{HCl} 4 \mathrm{~N}$.
Hal ini menunjukkan bahwa pengadukan berpengaruh pada distribusi pereaksi dalam reaktor serta berpengaruh pada pembentukan lapisan film. Semakin cepat putaran pengadukan akan menaikkan turbulensi fluida tersebut yang akan menurunkan ketebalan lapisan film sebagai batas antara pereaksi (dalam hal ini antara padatan dan cairan). Dengan menipisnya lapisan film tersebut akan mengakibatkan transfer massa antarfase semakin cepat. Namun, ketika proses pengadukan dinaikkan terus menjadi 240 rpm, data dalam grafik menunjukkan garis relatif mendatar. Kondisi ini menunjukkan bahwa proses pelindian terbaik terjadi pada kecepatan pengadukan $200 \mathrm{rpm}$ dengan zirkon terambil sebanyak $84,50 \%$.

Hasil analisis dengan menggunakan XRD menunjukkan karakteristik diffraktogram menunjukkan gambar yang serupa. Difraktogram ZOC olahan menyerupai ZOC pabrikan dengan perbedaan sedikit intensitasnya (Gambar 7 dan Gambar 8).

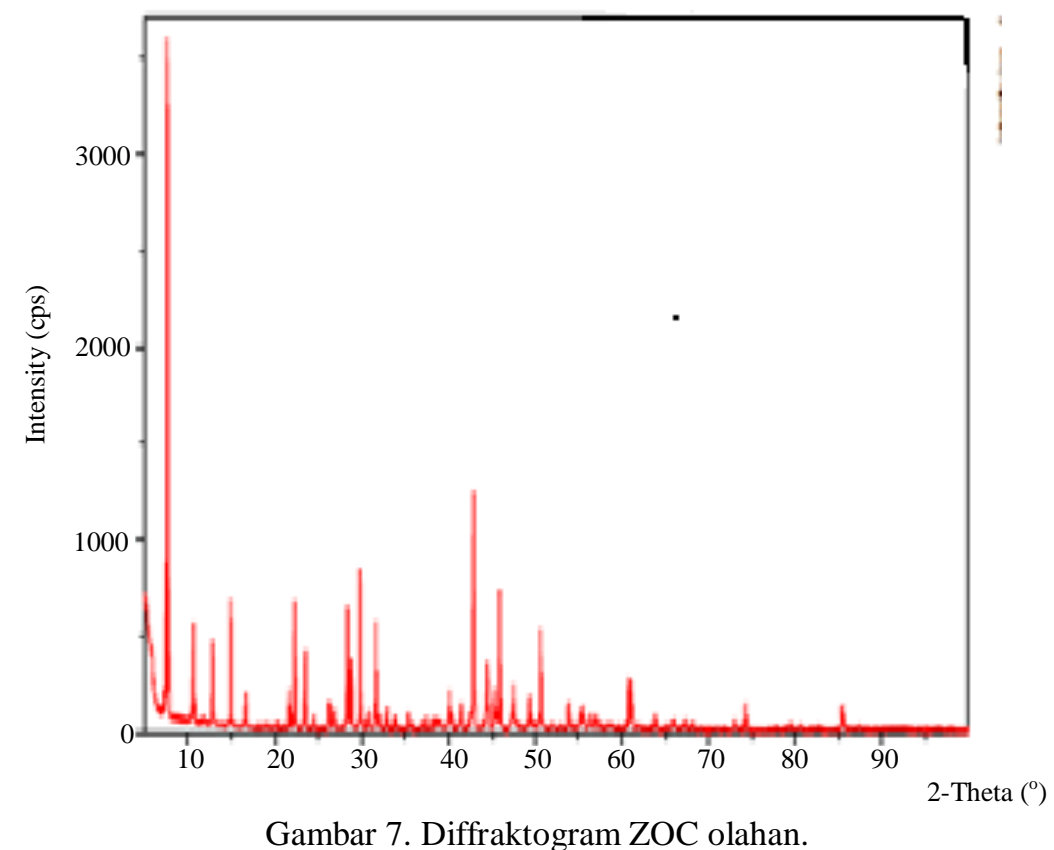




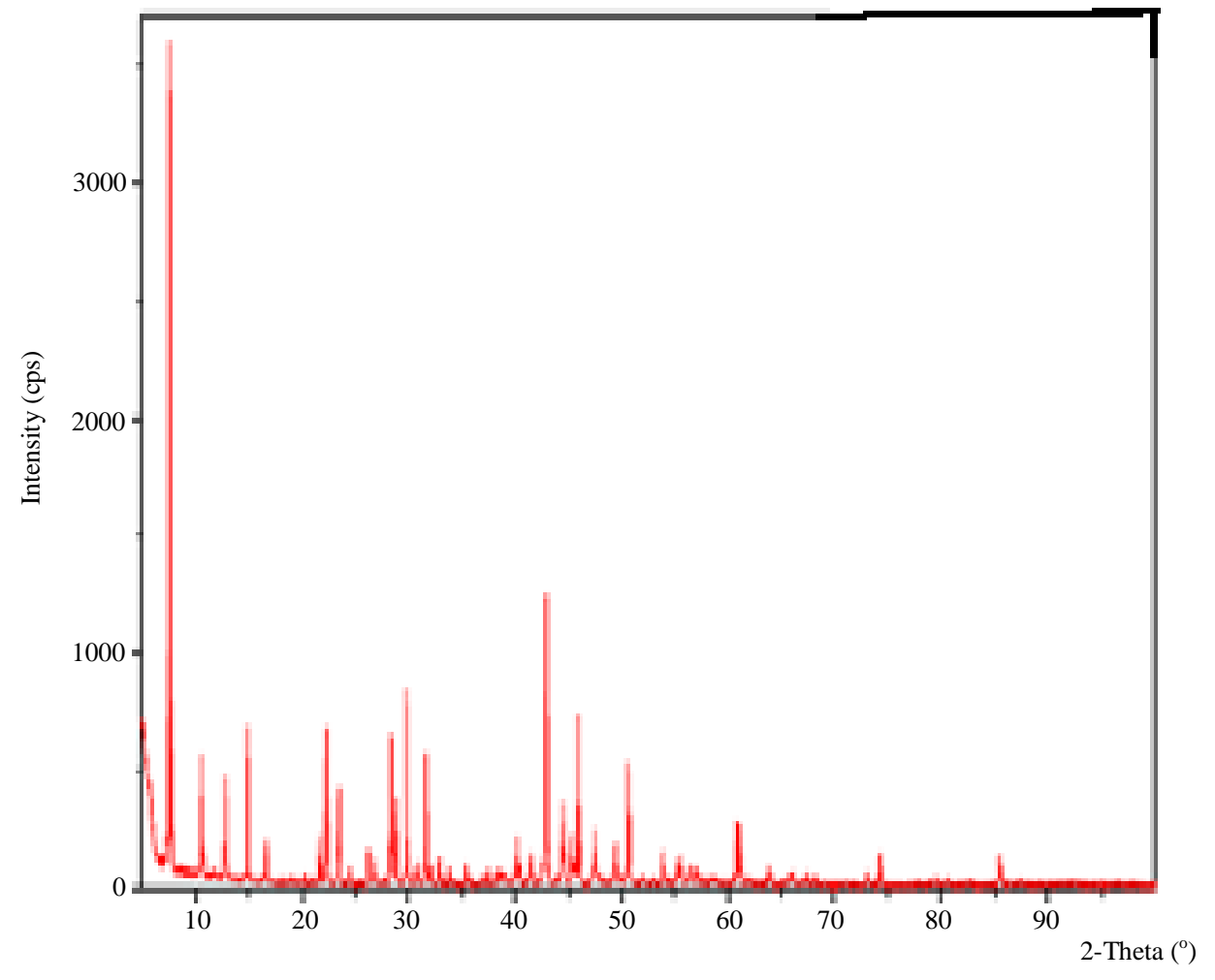

Gambar 8. Diffraktogram ZOC pabrikan.

\section{KESIMPULAN}

Ukuran butiran umpan, temperatur, dan kecepatan pengadukan berpengaruh dalam proses pelindian untuk memungut zirkon dari natrium zirkonat menggunakan pelarut $\mathrm{HCl}$ 4N. Hasil percobaan menunjukkan bahwa kondisi proses pelindian optimum pada ukuran butir $90 \mu \mathrm{m}$, temperatur $80{ }^{\circ} \mathrm{C}$, dan kecepatan putar pengaduk $200 \mathrm{rpm}$. Pada kondisi proses tersebut zirkon terambil atau larut dalam $\mathrm{HCl}$ sebanyak 84,60 \% .

\section{UCAPAN TERIMA KASIH}

Kami mengucapkan terima kasih kepada Pusat Sains dan Teknologi Akselerator Badan Tenaga Nuklir Nasional yang telah memberikan dana dan fasilitas serta Saudara Nurrohman Hafid yang telah membantu dalam pelaksanaan penelitian ini.

\section{DAFTAR PUSTAKA}

[1] Menteri Energi dan Sumberdaya Mineral, "Peraturan Menteri Energi dan Sumber Daya Mineral Nomor 5 Tahun 2017”, 2017.

[2] T. Suseno, "Analisis Biaya Pengolahan Pasir Zirkon (ZrSiO4) Menjadi Pasir Zirkon Berkadar $\mathrm{ZrO} 2 \geq 65,5 \%$ dan Micronized Zircon”, Jurnal Teknologi Mineral dan Batubara, 12, 179-194, 2016.

[3] C. Chai, "Global Zirconium Mark", Ceram. Ind. News, 1-12, 2012.

[4] R. Liu, T. Xue, J. Song, Y. Wang, T. Qi, J. Qu, and A. Du, "Removal of Silicon in Acid Leaching and Flocculation Processes during Zirconium Oxychloride Octahydrate Production", Ceramic International, 40(6), 8801-8808, 2014.

[5] Sajima and M. Setyadji, "Optimasi Proses Pelindian pada Pengambilan Uranium dan Thorium dalam Pembuatan Zircon Opacifier (ZrSiO 4 )", Jurnal Teknologi Bahan Nuklir, 11(2), 113-123, 2015.

[6] R. Septawendar, S. Sutardi, U. Karsono, and N. Sofiyaningsih, "A Low-Cost, Facile Method on Production of Nano Zirconia and Silica from 
Local Zircon in a Large Scale Using a Sodium Carbonate Sintering Technology", Journal of The Australian Ceramic Society, 52(2), 92-102, 2016.

[7] A. Gessi and G. Benamati, "Corrosion Experiments of Steels in Flowing $\mathrm{Pb}$ at $500{ }^{\circ} \mathrm{C}$ and in Flowing LBE at $450{ }^{\circ} \mathrm{C}$ ", Journal of Nuclear Materials, 76(3), 269-273, 2008.

[8] Y. Yuhelda, D. Amalia, and E. P. Nugraha, "Processing Zirconia through Zircon Sand Smelting with $\mathrm{NaOH}$ as a Flux", Indonesian Mining Journal, 19(1), 39-49, 2017.

[9] H. Poernomo, D. Biyantoro, and M. V. Purwani, "Kajian Konsep Teknologi Pengolahan Pasir Zirkon Lokal yang Mengandung Monasit, Senotim dan Ilmenit", Eksplorium, 37(2), 73-88, 2016.
[10] Sajima and Triyono, "Pelindian Leburan Pasir Zirkon Kalimantan Menggunakan Air Panas Bench Scale", Jurnal Forum Nuklir, 11(1), 1-6, 2017.

[11] R. J. F. Da Silva, A. J. B. Dutra, and J. C. Afonso, "Alkali Fusion Followed by a Two-Step Leaching of a Brazilian Zircon Concentrate", Hydrometallurgy, 117-118, 93-100, 2012.

[12] J. Zhang, L. Wang, and D. Jiang, "Decomposition Process of Zircon Sand Concentrate with CaONaOH”, Rare Metals, 31(4), 410-414, 2012.

[13] M. Rosidi, "Pengadukan dalam Proses KoagulasiFlokulasi”, Chemistry-Environment (ChemVi), 8 Juni 2015, [Online]. Tersedia: http://chemenvi.blogspot.com/2015/06/pengadukan-dalamproses-koagulasi.html. 